\title{
A Study on the Application of English Original Films in Oral English Teaching in Higher Vocational Colleges
}

\author{
Shuning Liu, Chunyan Teng \\ Guang'an Vocational and Technical College, China
}

\begin{abstract}
With the deepening of the globalization process, China's exchanges and cooperation with other countries are becoming closer and frequent, and the demand for proficient use of English and oral communication is becoming more and more urgent. Oral English is an important means and way of communication and cooperation with other countries. Therefore, it is helpful to strengthen the teaching of oral English in vocational colleges and to provide professional talents who are proficient in spoken English. The paper reviews motivation of learning oral English and the benefits of using original English films in oral English teaching. English movies have gained its popularity with more and more advantages recognized in higher vocational English teaching. English movies can not only arouse the students' interests to study English but also improve English teaching effect and teaching efficiency. So, this paper aims at how to apply English movies in higher vocational English teaching.
\end{abstract}

Keywords: Oral English teaching; English movies; Higher Vocational Colleges.

\section{Introduction}

As the rapid development of China's economy and information technology industry, more and more young college students have been equipped with a mobile phone, MP3 player, Walkman, computer and so on when they just entered the university. In addition, most vocational colleges have also established a different scale of the Internet or campus network to meet the development of the information age. In the contemporary China, more and more vocational English teachers begin to realize the importance of film in the growth of college students. Therefore, they begin to study how to integrate pop culture into the classroom teaching. With the deepening of college English teaching reform, the traditional college English teaching method cannot meet the current teaching requirements. It is a new trend to reform college English teaching by using computer information technology, reforming traditional college English teaching method, developing multimedia teaching resources, and reforming college English teaching mode as well as improving college English teaching effect.

The original English film is a good resource for opening the world of English language learning. If oral English can be learned effectively, then English teachers and students will gain a lot. The original English film used in college English oral teaching can be described as entertaining. Because the original English film as the carrier of language, it is derived from life, and the language itself is authentic spoken language. In the whole society with non-English environment, English language learning based on the original English film is an important channel for most Chinese college students and even for most Chinese English learners to speak authentic oral English and improve their oral English proficiency. Therefore, by applying the original English film to college English spoken language teaching, the enthusiasm of college students to learn oral English is fully mobilized, and the interest of learning is well excited. Their spoken language ability has been greatly improved, and intercultural communication ability also will be improved. Based on this social background, the original English film is used as a teaching resource in this paper, which analyses the theoretical basis of original English film applied to English oral teaching and discusses its teaching advantages [1].

\section{Research method}

According to the needs of research questions, this study involves the comprehensive application of various research methods. The specific research methods are designed as follows: 


\subsection{Literature research}

Around the film teaching and English oral teaching, through the all-round collection for various types of literature, this method makes a detailed analysis for the research status quo at home and abroad and finds the existing problems to clear the research innovation and direction.

\subsection{Questionnaire survey}

The two rounds of student questionnaires are designed, and the survey subjects is students. Through the first round of student questionnaires, we understand the current level of oral English proficiency in our vocational students and their attitude for the teaching of using the original English film in first round. Through the second round of student questionnaires, we understand the learning motivation of vocational students on oral English and their attitude for the teaching of using the original English film in second round.

\subsection{Action research method}

Through two rounds of action research, we mainly discuss how to influence the college students' oral English learning motivation and oral English ability by applying the original English film. The first round of action research discusses the level of oral English in Chinese vocational students at present and their attitude for the teaching of using the original English film in the first round. The second round of action explores the attitude of students for the application of the original English film in the second round and the level of their English learning motivation. After this, the experience summarized in the action research of first round is verified, and finally a set of operational teaching process is achieved.

\section{Theoretical Basis}

\subsection{Situated cognition theory}

Situation refers to a social environment in which a person is engaged in an action. It is the specific conditions produced by people's social behavior. The main connotations of contextual cognition can be summarized as follows: (1) Situations are the basis of all cognitive/learning and action, emphasizing the authenticity of context. (2) Knowledge is an application tool and the real result of the activity. In addition, knowledge is a social construction and performance in people's actions and community interaction [2]. (3) Learning is a process of actively participating in learning community/practice community and active interaction. (4) The use of cognitive tools/resources and the collaborative/social constructs of knowledge is emphasized. (5) Clear expression and reflection of learners is required in the process of learning. We study and understand the connotation of situated cognition theory, from which we can find that situated awareness theory holds that knowledge is learned through social construction in interaction with community. In addition, in the process of acquiring knowledge cognition and collaboration, learners play a very important role in learning knowledge [3]. In addition, situated awareness theory also attaches great importance to whether the evaluation results are true or false. For the responsibilities of teachers and learners, situated awareness theory also puts forward a clear request. Learners need to strengthen their understanding and reflection of the expression of knowledge, and teachers need to help learners to express understanding and reflection, so that learners can clearly express the learning process of understanding and reflection. In this way, the relationship between the teacher and the learner is to help each other [4].

From the perspective of this situation, the original English film has a very prominent advantage for learners to learn English oral knowledge. The original English film presents audiovisual excitement for all kinds of subjects, so that most students can understand the story-line in the film. These stories and themes can make students full of imagination, so the most prominent advantage of the original English film is to provide the context of discussion and communication for all kinds of topics. On the other hand, from the perspective of social construction, the original English film has same effects for learners to learn oral English knowledge. The original English film can be used in vocational English oral teaching. Through group discussions and other cooperative learning way, vocational students can obtain the new knowledge in the real situation. In short, according to situated awareness theory, the original English film is an indispensable teaching resources for learners and teachers [5]. 


\subsection{Language output hypothesis theory}

Spoken English is the activity of language output. In the past, for a long time, people only regard the output of language as the result of language acquisition or learning process, but little attention has been paid to the process itself. In response to this problem and based on Krashen's "language input hypothesis" theory, Swain proposed the "language output hypothesis" theory (Output Hypothesis). Swain thinks that language output has three functions such as attention/trigger function, test hypothesis function and meta-language function. The so-called attention/triggering function refers to that the language output can make learners aware of their own language deficiencies, so as to pay attention to the language of the new knowledge. The hypothesis function is that the learner needs to constantly make various assumptions about the target language while learning the foreign language, and the language output is the best way to detect the hypothesis. Meta-language function refers to that the learners use language to analyze and describe the language, which is the thinking of language form. Swain's research on meta-language function shows that language expression and language reflection have a positive effect in language acquisition [6].

Therefore, in vocational English oral teaching, teachers should design effective oral output activities, so as to promote oral learning, master the correctness and fluency of spoken language. The oral output activities should be designed for students to communicate with each other and to develop students' oral output ability.

\section{The Advantages of Original English Movies in Oral English Teaching}

\subsection{To improve students' interest in learning.}

Traditional teaching methods on oral English are relatively backward, which is divorced from the real life. It cannot cause students interested. Therefore, students do not want to spend a lot of time on English learning, resulting in a low enthusiasm of vocational students on the oral English learning. In order to improve the teaching quality of spoken English in higher vocational colleges and the teaching methods, the original film is introduced into the oral English classroom of higher vocational education and become a new English teaching model, which attracts students' interest. Interest is the best motivation for students to learn English and the key to improve students' learning efficiency. Therefore, students must be interested in learning English. The film is the best form of art, which combines language and painting. It can effectively attract students' attention and interest. In addition, it also can achieve the teaching objectives and create a relaxed teaching atmosphere. It is a good way to improve students' interest in learning English through the original English film [7].

\subsection{To improve students' oral skills.}

The original English film contains a lot of foreign culture and customs, which has a certain cultural background. The original English film presents the foreign culture, customs and history in front of students through the image. The vocational students can feel the charm of language and culture and learn oral English in a good language environment. In addition, the original English film can provide students with the standard pronunciation of spoken English, the use of spoken English grammar and the use of vocabulary in vocabulary. Pronunciation exercises are the basis for learning spoken English and the premise of improving spoken English. In the original English film, the actors have a standard pronunciation, and articulation is also very clear, which can improve student's English spoken pronunciation. Through the English soundtrack film, students can understand the spoken English clearly. Therefore, students should learn oral English in the real language environment and enhance their oral English ability through pronunciation imitation [8]. The three steps of viewing English film is shown in Table 1: 
Table 1. Teaching process and implementation structure

\begin{tabular}{|c|c|c|}
\hline \multirow{3}{*}{ Before viewing } & $\begin{array}{c}\text { Teachers } \\
\text { Teachers should prepare the film } \\
\text { and self-study materials, and show } \\
\text { the problem about before viewing. } \\
\text { Students are divided into groups to } \\
\text { discuss the problem. }\end{array}$ & $\begin{array}{c}\text { Students discuss their subject in the } \\
\text { group. They also have to write } \\
\text { down the words and phrases } \\
\text { encountered in the discussion. } \\
\text { After discussion, a leader was } \\
\text { elected to speak. }\end{array}$ \\
\hline In viewing & $\begin{array}{c}\text { Teachers play the movie and ask } \\
\text { students to take notes in the } \\
\text { viewing process. Teacher can stop } \\
\text { and explain the difficult part for } \\
\text { students on occasion. }\end{array}$ & $\begin{array}{c}\text { When watching the film, students } \\
\text { are required to record the words } \\
\text { appeared in the film. Students can } \\
\text { digest and absorb this new words } \\
\text { after the viewing. }\end{array}$ \\
\hline After viewing & $\begin{array}{c}\text { Teachers present the problem about } \\
\text { after viewing. Students are } \\
\text { required to discuss the question } \\
\text { with the group member. After the } \\
\text { discussion, some guidance and } \\
\text { evaluation are proposed by teacher. }\end{array}$ & $\begin{array}{c}\text { The discussion about after viewing } \\
\text { is same as the method used in } \\
\text { before viewing. Students are } \\
\text { required to show their notes and } \\
\text { explain it to the teacher. }\end{array}$ \\
\hline
\end{tabular}

\section{Conclusion}

On the basis of tracking the development history of film teaching and vocational oral English teaching research at home and abroad, this paper focuses on the process of action research of original English film in vocational oral English teaching and discusses a set of teaching process. This paper also explores student's attitude for the teaching of using the original English film through the theoretical hypothesis analysis to the practical investigation. Through the research for the theme of "original English film in college English oral teaching application", the following important conclusions are formed: (1) The application of the original English film for vocational English oral teaching can improve the efficiency of English teaching, which can enhance student's motivation on oral English learning and improve the proficiency of oral English. (2) Effective film teaching process includes three stages. The design of teacher's teaching activities plays an important role in the process of film viewing.

\section{References}

[1] Xing, Z. L. Some advantageous uses of video in English teaching [J]. Journal of Changchun University of Science and Technology, 2005, 18(1), 25-27.

[2] Wang Pei. The Advantages of the Application of English Original Films in English Teaching for Students from Higher Vocational and Technical Institutions [J]. Overseas English, 2012,24:98-99.

[3] Zhang Wenjian. Strategies in Oral English Teaching in Normal Schools [J]. Reading and writing (Education published), 2012, 11:6.

[4] Moody. How Can A Chinese Teacher of English succeed in Oral English class [J]. Zhengde College Journal, 2006, 01:61-65.

[5] Li Yanjun. Oral English Improvement: by Watching Original Films-A Positivism Research Based on the English Screenplay Corpus [J]. Overseas English, 2013, 05:95-97.

[6] XIAO, L. H. Effect factors and coping strategies of university English listening teaching [J]. Journal of Shenyang Normal University, 2008, 33(21), 57-59.

[7] Li, J.Y. Application of original films in college oral English teaching. Journal of Yichun College, 2011, 33(2), 167-169.

[8] Inozu, J. Beliefs about foreign language learning among students training to teach English as a foreign language. Social Behavior and Personality, 2011, 39(5),645-654. 